\title{
Characteristics of the Ahmadabad hematite/barite deposit, Iran - studies of mineralogy, geochemistry and fluid inclusions
}

\author{
Amir Haji Babaei ${ }^{1 *}$, Alireza Ganji ${ }^{1}$ \\ ${ }^{1}$ Department of Geology, Faculty of Sciences, Lahijan Branch, Islamic Azad University, Lahijan, Iran \\ *corresponding author, e-mail: amirhajibabaey@gmail.com
}

\begin{abstract}
The Ahmadabad hematite/barite deposit is located to the northeast of the city of Semnan, Iran. Geostructurally, this deposit lies between the Alborz and the Central Iran zones in the Semnan Subzone. Hematite-barite mineralisation occurs in the form of a vein along a local fault within Eocene volcanic host rocks. The Ahmadabad deposit has a simple mineralogy, of which hematite and barite are the main constituents, followed by pyrite and Fe-oxyhydroxides such as limonite and goethite. Based on textural relationships between the above-mentioned principal minerals, it could be deduced that there are three hydrothermal mineralisation stages in which pyrite, hematite and barite with primary open space filling textures formed under different hydrothermal conditions. Subsequently, in the supergene stage, goethite and limonite minerals with secondary replacement textures formed under oxidation surficial conditions. Microthermometric studies on barite samples show that homogenisation temperatures $\left(\mathrm{T}_{\mathrm{H}}\right)$ for primary fluid inclusions range from 142 to $256^{\circ} \mathrm{C}$ with a temperature peak between 200 and $220^{\circ} \mathrm{C}$. Salinities vary from 3.62 to $16.70 \mathrm{NaCl}$ wt $\%$ with two different peaks, including one of 6 to $8 \mathrm{NaCl} w \mathrm{t} \%$ and another of 12 to $14 \mathrm{NaCl} \mathrm{wt} \%$. This indicates that two different hydrothermal waters, including basinal and sea waters, could have been involved in barite mineralisation. The geochemistry of the major and trace elements in the samples studied indicate a hydrothermal origin for hematite and barite mineralisation. Moreover, the Fe/Mn ratio (>10) and plots of hematite samples of Ahmadabad ores on Al-Fe$\mathrm{Mn}, \mathrm{Fe}-\mathrm{Mn}-(\mathrm{Ni}+\mathrm{Co}+\mathrm{Cu}) \times 10$, Fe-Mn-SiX and $\mathrm{MnO} / \mathrm{TiO}_{2}-\mathrm{Fe}_{2} \mathrm{O}_{3} / \mathrm{TiO}_{2}$ diagrams indicate that hematite mineralisation in the Ahmadabad deposit occurred under hydrothermal conditions. Furthermore, Ba and Sr enrichment, along with $\mathrm{Pb}, \mathrm{Zn}, \mathrm{Hg}$, $\mathrm{Cu}$ and $\mathrm{Sb}$ depletion, in the barite samples of Ahmadabad ores are indicative of a low temperature hydrothermal origin for the deposit. A comparison of the ratios of $\mathrm{La}_{\mathrm{N}} / \mathrm{Yb}_{\mathrm{N}^{\prime}}, \mathrm{Ce}_{\mathrm{N}} / \mathrm{Yb}_{\mathrm{N}^{\prime}} \mathrm{Tb}_{\mathrm{N}} / \mathrm{La}_{\mathrm{N}^{\prime}}, \mathrm{Sm}_{\mathrm{N}} / \mathrm{Nd}_{\mathrm{N}}$ and parameters of $\mathrm{Ce} / \mathrm{Ce}^{*}$ and $\mathrm{La} / \mathrm{La}^{*}$ anomalies of the hematite, barite, host volcanic rocks and quartz latite samples to each other elucidate two important points: 1) the barite could have originated from volcanic host rocks, 2) the hematite could have originated from a quartz latite lithological unit. The chondrite normalised REE patterns of samples of hematite barite, volcanic host rocks and quartz latite imply that two different hydrothermal fluids could be proposed for hematite and barite mineralisation. The comparison between chondrite normalised REE patterns of Ahmadabad barite with oceanic origin barite and low temperature hydrothermal barite shows close similarities to the low temperature hydrothermal barite deposits.
\end{abstract}

Key words: geochemistry, trace and rare earth elements, Semnan

\section{Introduction}

Concentrations of REEs in hydrothermal fluids may yield useful data regarding the origin of ore-forming elements (Kato, 1999). As REEs can be fractionated during geochemical processes, REE patterns nor- 
malised to standard material have been widely used as a tool to reveal various geochemical processes (Kato, 1999). Moreover, microthermometry of fluid inclusions can potentially serve as indicator of the physico-chemical environment of barite mineralisation (Zarasvandi et al., 2014). The origin of iron and barite deposits in the Alborz Zone has always been an issue of controversy in many studies. During the Cenozoic, an extensive barite mineralisation in connection with volcanosedimentary rocks took place in the Alborz Zone. Barite deposits, in the form of veins, lenses and layers, are abundantly seen in Eocene and Oligocene volcanic and pyroclastic rocks in several areas of the Alborz Zone such as Qazvin, Karaj and Semnan (Ghorbani, 2013). However, no comprehensive research has been conducted on the formation of the Ahmadabad hematite-barite deposit. The present study reports on detailed investigations, including textural, mineralogical and microthermometrical studies, together with geochemistry

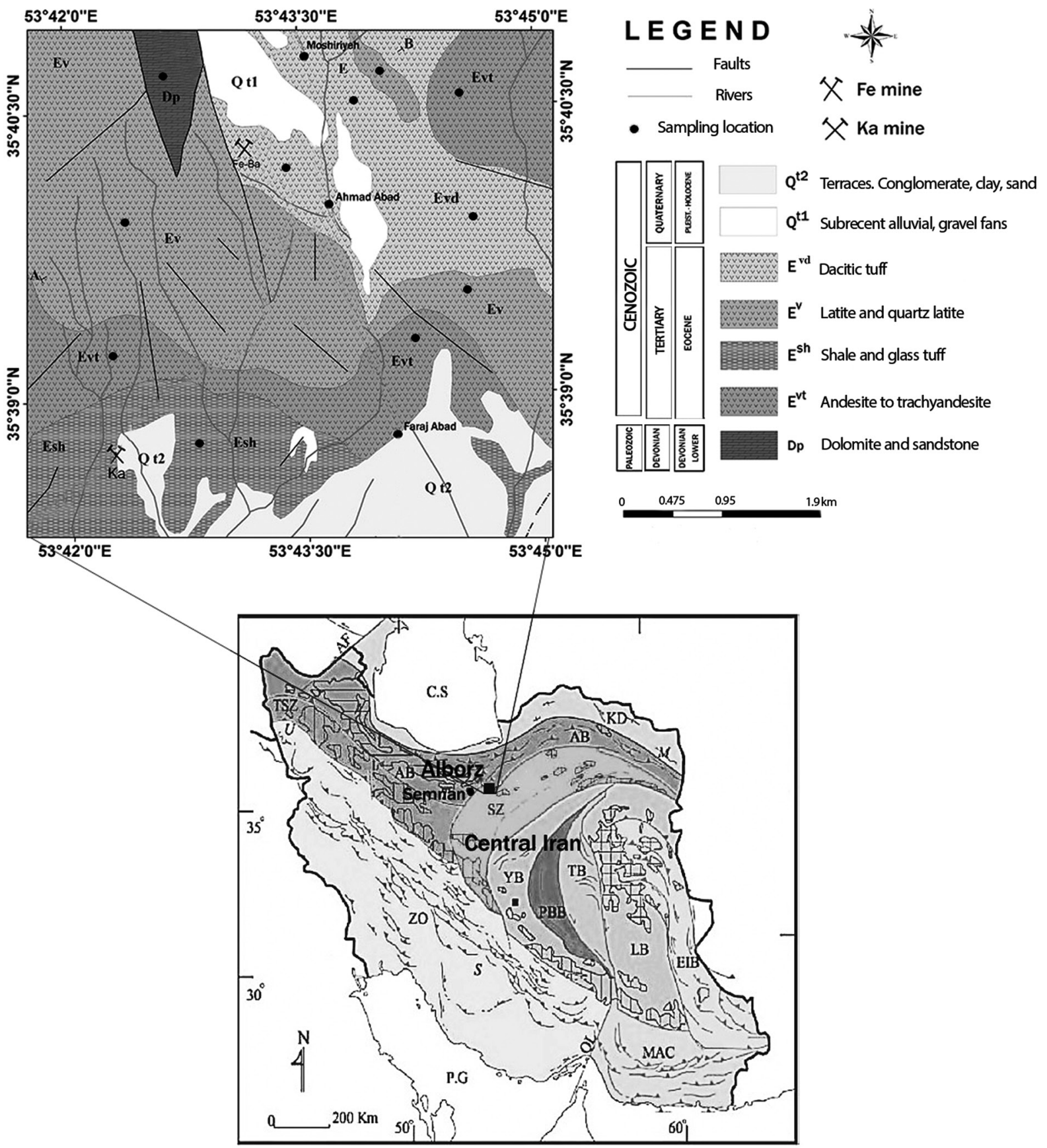

Fig. 1. Geological map of the study area (scale 1:20,000, based on Alavi, 2005). 
of major, trace and rare earth elements studies in the host rock, as well as on the hematite-barite mineralisation. Finally, based on these studies, the origin of the Ahmadabad deposit is worked out.

\section{Geological setting}

The study area is located $40 \mathrm{~km}$ northeast of the city of Semnan and at northern latitudes of $35^{\circ} 39^{\prime}$ to $35^{\circ} 40^{\prime}$ and eastern longitude of $53^{\circ} 42^{\prime}$ to $53^{\circ} 45^{\prime}$ (Fig. 1). The study area is situated on the border of the Central Iran and Alborz geostructural zones in the shear zones of a main local fault, the Atari fault. The main lithostratigraphical units which are exposed in the area are Lower Devonian dolomite and sandstone, an Eocene sequence including andesite, trachyandesite, shale, glass tuff, latite and dacite as well as quartz latite and Quaternary alluvial terraces, including conglomerate, sandstone and claystone (Alavi, 2005) (Fig. 1). The hydrothermally altered zones which are present in the host rocks are weak to moderate argillic types. Hematite-barite mineralisation occurs as a main vein in the volcanic host rocks. The hanging wall of the vein is composed of dacite and the footwall is a tuff. This vein is $100 \mathrm{~m}$ in length and $2-5 \mathrm{~m}$ thick. Hematite and barite are the main constituents, followed by pyrite and Fe-oxyhydroxides such as limonite and goethite in the mineralised vein. Our field observations of the mineralised vein indicate that barite formed after hematite because hematite veinlets are cut by barite veinlets. The predominant texture of the hematite/barite mineralisation is that of open space filling (Evans, 2009), which forms between brecciated fragments of host rocks.

\section{Methods}

Sampling was carried out in the Spring of 2012. A geological map (scale of 1:20,000), based on the geological map of 1:100,000 (Alavi, 2005), was compiled by using Arc GIS software. After fieldwork, 30 samples were selected for petrographical studies. The petrographical and mineralogical studies, using 19 thin and 11 polished sections from surrounding and host rocks and also from hematite/barite ores, were done at the microscopy laboratory of the Lahijan branch of the Islamic Azad University. The fluid-inclusion microthermometric studies were done on three double-polished thin section samples using standard techniques. The parameters that were measured included the last ice-melting temperature $\left(\mathrm{Tm}_{\mathrm{ice}}\right)$ and homogenisation temperature
$\left(\mathrm{T}_{\mathrm{H}}\right)$ (Table 1). The measurements were performed on a Linkam THMS 600 combined heating/freezing stage that was installed on a Zeiss microscope at the Iranian Mineral Processing Research Centre. The temperature range of the device is from -196 to $+600^{\circ} \mathrm{C}$. It is also equipped with two controllers, heating (TP94) and cooling (LNP), nitrogen tank (to pump nitrogen for freezing) and water tank (to cool the device at high temperatures). In order to study the geochemistry of trace and rare earth elements, nine samples were analysed using ICP-MS, as well as two samples using ICP-AES in the Zarazma Mineral Studies Company. Furthermore, seven samples were analysed by the XRF method in the Kanpazhouh Mineralogical \& Geological Research Centre in Tehran. Major oxides, including $\mathrm{SiO}_{2}$, $\mathrm{Al}_{2} \mathrm{O}_{3^{\prime}}, \mathrm{Fe}_{2} \mathrm{O}_{3^{\prime}} \mathrm{MgO}, \mathrm{TiO}_{2}, \mathrm{CaO}, \mathrm{K}_{2} \mathrm{O}$ and $\mathrm{P}_{2} \mathrm{O}_{5}$, were measured by using XRF method. $\mathrm{Ba}, \mathrm{Cr}, \mathrm{Li}, \mathrm{Mn}, \mathrm{S}$, $\mathrm{Sc}, \mathrm{Sr}, \mathrm{V}$ were analysed by using the acid-digestion inductively coupled plasma-optical emission spectrometry analysing method (ICP-OES). REEs were analysed by inductively coupled plasma- mass spectrometry analysing methods (ICP-MS), using microwave-assisted multi-acid digestion.

\section{Results and discussion}

\subsection{Petrography}

Based on conducted petrographical studies, the surrounding and host rocks of the Ahmadabad deposit fall into five main groups, including andesite, trachyandesite, quartz latite, latite, dacite and vitric tuff. Andesite to trachyandesite rocks (Evt unit in Fig. 1) have a porphyric texture with a vitric matrix containing phenocrysts of automorphic plagioclase crystals which are completely transformed to clay minerals, quartz crystals (about 5\%), alkali feldspar (in small amounts) and some euhedral opaque minerals in the plagioclase phenocrysts as poikilitic texture, which indicates that these minerals crystallised prior to plagioclase (Fig. 2A). Quartz latite rocks (Ev unit) are exposed in highs of the study area; these rocks have a porphyric texture with a vitric matrix (Fig. 2B). Dacitic tuff (Evd unit), which is the host rock of the Ahmadabad deposit characterised by porphyric texture with a vitric matrix (Fig. 2C). The predominant phenocryst in these rocks is euhedral to subhedral plagioclase with polysynthetic twining which have been completely altered and transformed to clay minerals. Some opacitic amphibole crystals can be observed in the rocks. Latite shows a porphyric texture with a microgranular matrix 


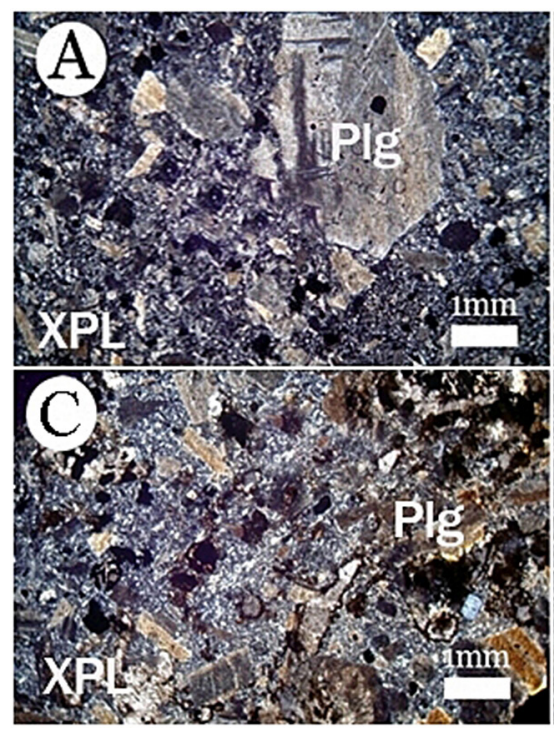

and their major phenocryst is plagioclase which has been highly altered and transformed to clay minerals (Fig. 2D).

\subsection{Mineralogy}

Mineralogical studies show that the principal minerals in order of their frequency comprise hematite, barite, pyrite, goethite and other Fe-oxyhydroxides and magnetite.

Hematite mineralisation, surrounding pyrite minerals, is observed in all samples studied. The mineralisation occurs along fractures in the form of an open space filling texture. In addition, with respect to the formation of breccia texture along the host rock fractures, it can be concluded that the brecciation of the host rock formed before miner-
Fig. 2. Microscopic images of rock samples studied. A - Andesite and trachyandesite with porphyric texture and vitric matrix. A predominance of altered plagioclase phenocrysts can be seen (Plg: plagioclase); B - Quartz latite with porphyric texture and vitric matrix (Op. Am: opacitic amphibole); C - Dacite and vitric tuff with porphyric texture and vitric matrix (Plg: plagioclase); D - Latite with porphyric texture and microgranular matrix and predominant altered plagioclase phenocrysts (Plg: plagioclase).

alisation. The brecciation could have been induced by two factors: (1) Structural factors, caused by the activity of the local fault controlling mineralisation. (2) Hydrostatic pressure caused by mineralising hydrothermal fluids. In some samples hematite mineralisation can be seen as separated tabular crystals. The mineralisation co-occurs with the formation of automorph quartz. Moreover, Fe-oxyhydroxides minerals, such as goethite, which are formed by hematite oxidation, have been observed with a boxwork texture (in which goethite is formed as stockwork lamellae in the framework of primary hematite crystals) (Fig. 3).

Microscopic studies indicate that barite mineralisation occurs in different shapes. Coarse and long grains of barite as joint infillings and blade-shaped and crushed fine crystals of barite occur mostly as vein-filling textures (Fig. 4A, B).
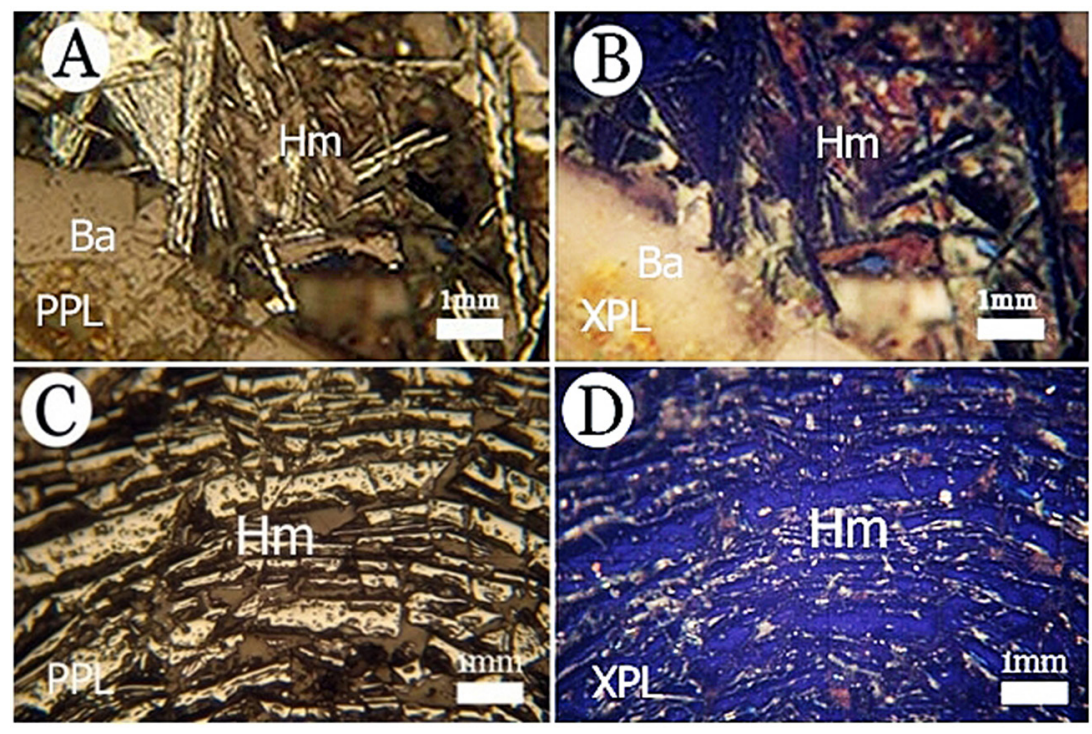

Fig. 3. Microscopic images of hematite mineralisation. Tabular specularite crystals with open space filling primary texture, have filled pores between brecciated fragments of host rock. 


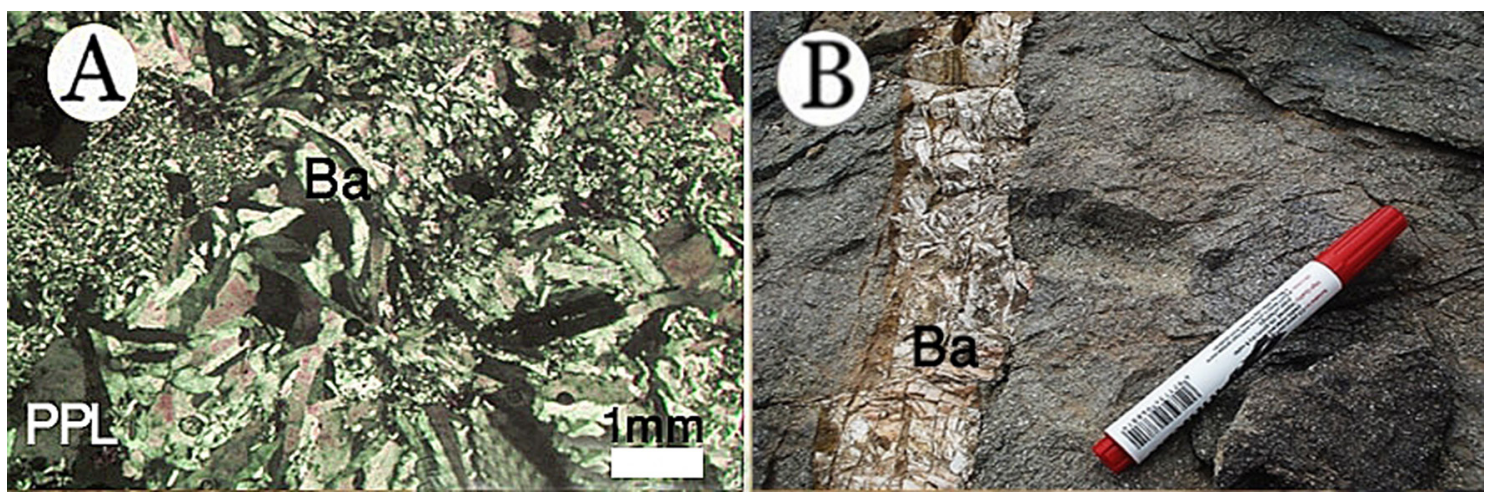

Fig. 4. A - Microscopic image of barite as fine- and coarse-grained crystals (Ba); B - Barite veinlet (Ba) in the quartz latite host rock. Pencil is $15 \mathrm{~cm}$ long.

Pyrite crystals can be seen in the form of euhedral (Fig. 5A) and subhedral crystals in most of the samples studied; crystals are marginally oxidised and transformed to Fe-oxyhydroxides, including goethite and limonite in such a way that some of them show complete transformation (Fig. 5A, B). Pyrite crystals are surrounded by hematite crystals in the open space filling texture. The frequency of pyrite minerals in the samples studied is approximately between 1 and $5 \%$. The pyrite crystals often show a polygonal morphology in which the pyrite grains are adopted with triple junctions of approximately 120 degrees (Fig. 5C, D). In addition, hematite crystals surrounding pyrite crystals indicate that hematite formed after pyrite.

For goethite and other Fe-oxyhydroxide minerals the following can be stated. In most of the samples studied, pyrite crystals have transformed into Fe-oxyhydroxides, especially goethite, as a result of the oxidation process, which indicate a second- ary replacement texture. The intensity of the oxidation process was so strong that almost all of the pyrite crystals have been completely transformed. In the primary hydrothermal mineralisation stage, pyrite, hematite and barite minerals formed under different physico-chemical conditions from related hydrothermal fluids. In the secondary mineralisation stage (supergene), goethite, limonite, gypsum and calcite formed under surficial oxidation conditions as a result of chemical weathering of primary minerals. Based on textural relationships between the above-mentioned principal minerals, it could be concluded that there are three hydrothermal mineralisation stages in which pyrite, hematite and barite with primary open space filling textures formed under different hydrothermal conditions. Subsequently, in the supergene stage, goethite, limonite minerals with secondary replacement textures formed under oxidation surficial conditions (Fig. 6).
Fig. 5. A, B - Microscopic images of coarse-grained euhedral to subhedral pyrite crystals with polygonal morphology which are surrounded by hematite tabular crystals; C, D - Microscopic images of pyrite crystals in which the crystals adopt a polygonal morphology with grain triple junctions of approximately 120 degrees.
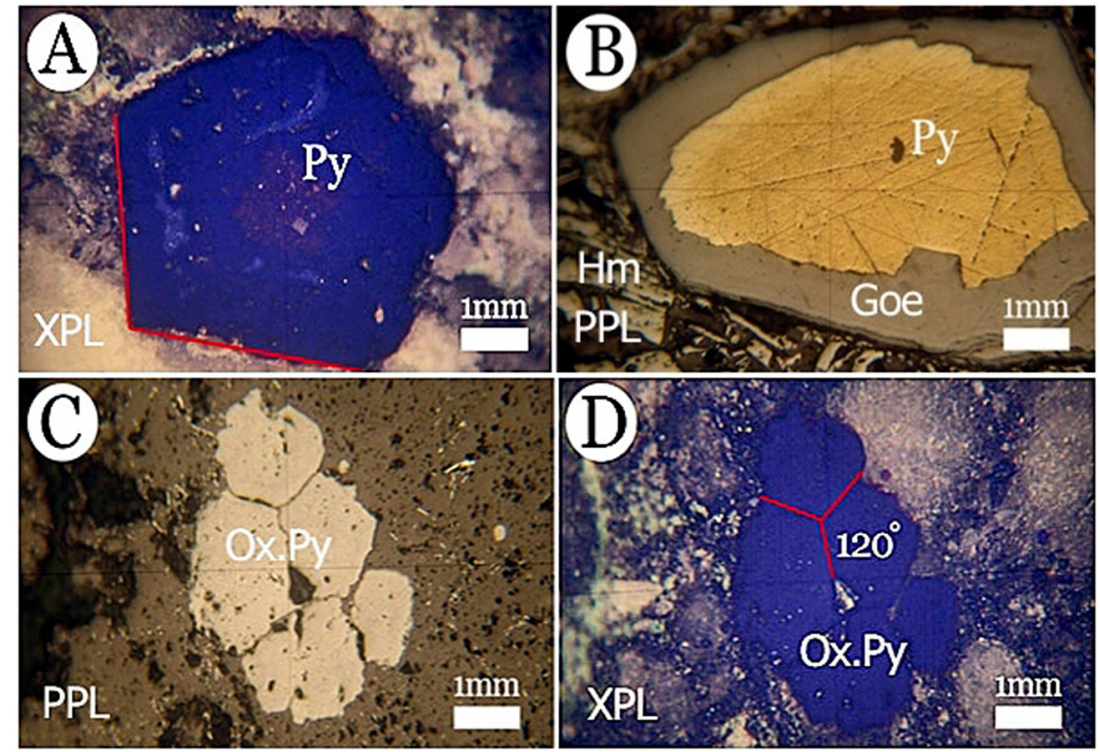


\begin{tabular}{llll}
\multicolumn{1}{c}{ Stage } & \multicolumn{2}{c}{ Early } & \multicolumn{1}{c}{ Late } \\
\cline { 1 - 2 } Mineral & \multicolumn{2}{c}{ Hydrothermal mineralization stage } & Supergene stage \\
Pyrite & I II & \\
Hematite & \\
Barite \\
Goethite \\
Limonite
\end{tabular}

Fig. 6. Generalised paragenetic sequence of the Ahmadabad hematite/barite deposit based on petrographical and mineralographical studies.

\subsection{Microthermometry of fluid inclusions}

Fluid inclusions were studied in three selected barite samples that had been collected from the hematite/barite mineralised main vein and one of the barite veinlets. According to the genetic classification of Roedder (1984), the inclusions studied are primary $(\mathrm{P})$, pseudosecondary (PS) and secondary (S) in character and have varying shapes and sizes. Most fluid-inclusion types in the barite samples studied are primary, in addition to lower amounts of secondary inclusions and also pseudosecondary inclusions which are rarely found. Their sizes vary from 7 to $16 \mu \mathrm{m}$. In general, the fluid inclusions can be morphologically divided into two groups: 1 . inclusions with regular polygonal shapes and 2 . stretched inclusions. These types were studied microthermometrically, while individuals that showed symptoms of necking down or leakage were ignored (compare Ulrich \& Bodnar, 1988). The inclusions can be divided into three groups: 1) twophase liquid-vapour (liquid-rich); 2) monophase (only liquid phase) and 3) monophase (only vapour phase). Primary and pseudosecondary inclusions are consistently simple two-phase liquid-vapour types with no daughter mineral or separated $\mathrm{CO}_{2}$ phase at room temperature. Temperature parameters were measured in two-phase liquid-vapour (liquid-rich) inclusions. The results are shown in Figure 7 and Table 1 . The values of $T_{H}$ measured for more than 40 fluid inclusions of the barite samples studied range from 142 to $256^{\circ} \mathrm{C}$, with peaks at 200 to $220^{\circ} \mathrm{C}$ (Fig. 8A), with an average of $166^{\circ} \mathrm{C}$. During measurements of $\mathrm{T}_{\mathrm{H}^{\prime}}$ vapour $(\mathrm{L}+\mathrm{V})$ inclusions became homogenised in the liquid phase (Table 1). $T_{H}$ values are good estimates of mineralisation temperatures. The values of $\mathrm{Tm}_{\text {ice }}$ varied from -17.8 to $-2.7^{\circ} \mathrm{C}$ (Table 1 ), with an average of $-10.9^{\circ} \mathrm{C}$. The salinity of fluid inclusions (in $\mathrm{wt} \% \mathrm{NaCl}$ eq.) was estimated from the $\mathrm{T}_{\mathrm{IM}}$ data using the equation of
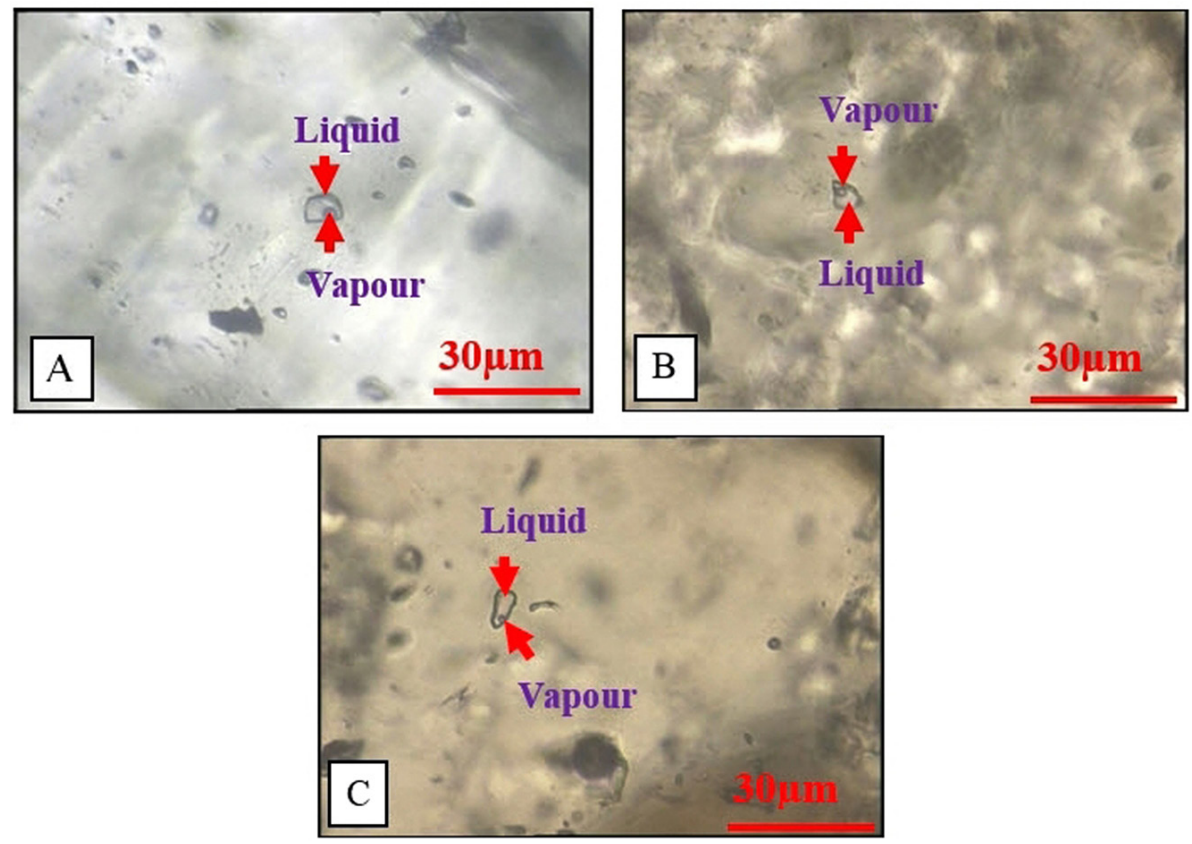

Fig. 7. Types of fluid inclusions within the barite crystals studied. A - Sample no. H10. Two-phase vapour, liquid rich; $\mathbf{B}$ - sample no. H11. Twophase (liquid/vapour) inclusions; C - sample no. H15-1. Two-phase (liquid/vapour) inclusions. 

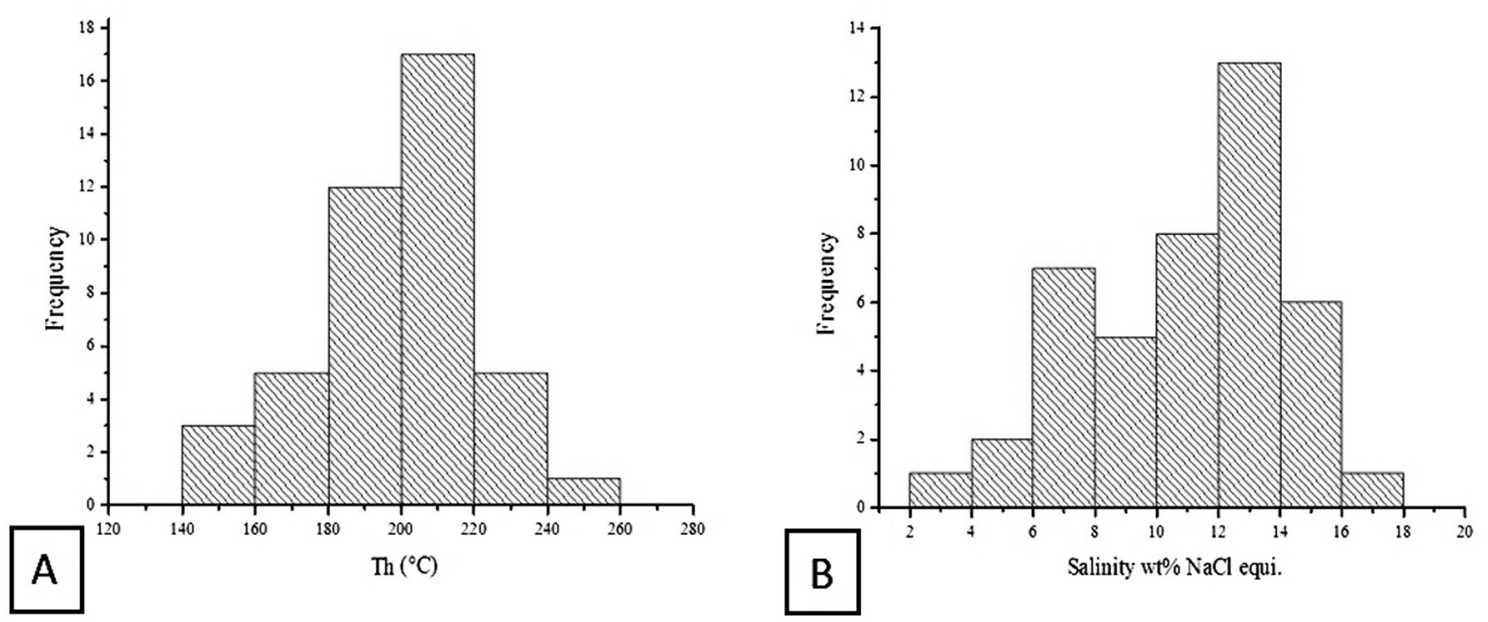

Fig. 8. Frequency distribution of parameters measured for fluid inclusions studied in barite samples of the Ahmadabad deposit. A - Homogenisation temperature $\left(\mathrm{T}_{\mathrm{H}}\right)$; B - Salinity (equiv. wt. \% $\mathrm{NaCl}$ ).

Fig. 9. Detection of mineralising fluids in the Ahmadabad deposit using salinity vs. homogeneous temperature histogram (after Kesler, 2005).

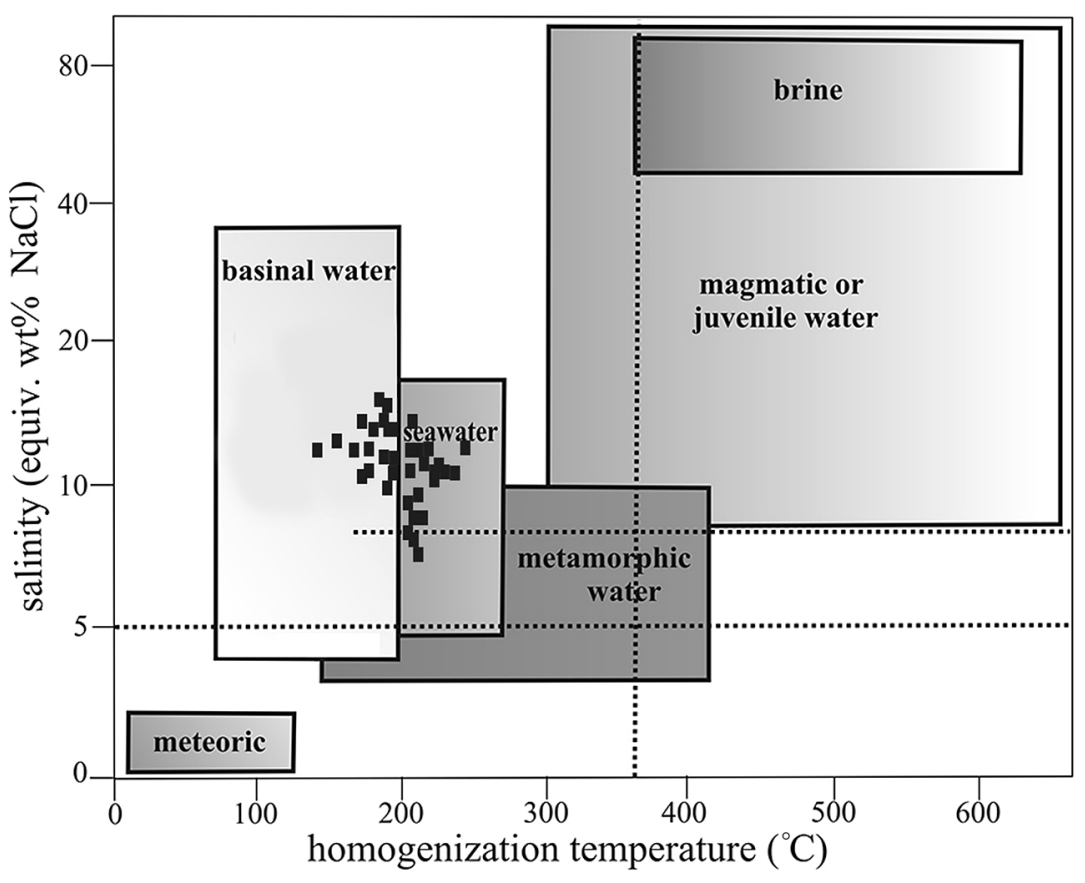

Table 1. Microthermometric data of fluid inclusions in samples from the Ahmadabad hematite/barite deposit studied (MMV: main mineralised vein in H10 \& H11, VLB: veinlet in the body in H15).

\begin{tabular}{|c|c|c|c|c|c|c|c|c|c|c|}
\hline $\begin{array}{c}\text { Sample } \\
\text { no. }\end{array}$ & Texture & Homoge-nization types & $\begin{array}{l}\text { Size } \\
(\mu \mathrm{m})\end{array}$ & $\begin{array}{c}\mathrm{Te} \\
\left({ }^{\circ} \mathrm{C}\right)\end{array}$ & $\begin{array}{l}\operatorname{Tm}_{\text {ice }} \\
\left({ }^{\circ} \mathrm{C}\right)\end{array}$ & $\begin{array}{l}\operatorname{Tm}_{\mathrm{hh}} \\
\left({ }^{\circ} \mathrm{C}\right)\end{array}$ & $\begin{array}{l}\text { wt } \% \\
\mathrm{NaCl}\end{array}$ & $\begin{array}{l}\mathrm{TH} \\
\left({ }^{\circ} \mathrm{C}\right)\end{array}$ & $\begin{array}{c}\mathrm{wt} \% \\
\mathrm{CaCl}_{2}\end{array}$ & $\mathrm{wt} \% \mathrm{NaCl}+\mathrm{CaCl}_{2}$ \\
\hline H10 & Barite(MMV) & LV & 10 & -45 & -11 & -23 & 11.4706 & 217 & 3.4696 & 14.9402 \\
\hline H10 & Barite(MMV) & LV & 8 & -52 & -5.5 & -22.7 & 7.0906 & 199 & 1.7524 & 8.843 \\
\hline $\mathrm{H} 10$ & Barite(MMV) & LV & 8 & -52 & -5.6 & -22 & 7.9318 & 142 & 1.0037 & 8.9354 \\
\hline H10 & Barite(MMV) & $\mathrm{LV}$ & 8 & -52 & -12.8 & -24 & 10.9753 & 225 & 5.5233 & 16.4987 \\
\hline $\mathrm{H} 10$ & Barite(MMV) & LV & 12 & -60 & -4.7 & -22.6 & 6.2977 & 194 & 1.4434 & 7.7411 \\
\hline H10 & Barite(MMV) & $\mathrm{LV}$ & 10 & -52 & -12.7 & -23 & 12.6311 & 190 & 3.8206 & 16.4518 \\
\hline $\mathrm{H} 10$ & Barite(MMV) & LV & 10 & -52 & -5.5 & -22.1 & 7.7058 & 214 & 1.1024 & 8.8082 \\
\hline $\mathrm{H} 10$ & Barite(MMV) & LV & 8 & -52 & -5.5 & -22 & 7.8136 & 209 & 0.9887 & 8.8023 \\
\hline $\mathrm{H} 10$ & Barite(MMV) & LV & 10 & -52 & -2.7 & -23 & 3.6239 & 230 & 1.0961 & 4.72 \\
\hline H10 & Barite(MMV) & $\mathrm{LV}$ & 8 & -48 & -2.8 & -22 & 4.2675 & $212 / 5$ & 0.54 & 4.8075 \\
\hline
\end{tabular}




\begin{tabular}{|c|c|c|c|c|c|c|c|c|c|c|}
\hline $\begin{array}{c}\text { Sample } \\
\text { no. }\end{array}$ & Texture & Homoge-nization types & $\begin{array}{l}\text { Size } \\
(\mu \mathrm{m})\end{array}$ & $\begin{array}{c}\mathrm{Te} \\
\left({ }^{\circ} \mathrm{C}\right)\end{array}$ & $\begin{array}{l}\mathrm{Tm}_{\text {ice }} \\
\left({ }^{\circ} \mathrm{C}\right)\end{array}$ & $\begin{array}{l}\mathrm{Tm}_{\mathrm{hh}} \\
\left({ }^{\circ} \mathrm{C}\right)\end{array}$ & $\begin{array}{l}\mathrm{wt} \% \\
\mathrm{NaCl}\end{array}$ & $\begin{array}{l}\mathrm{TH} \\
\left({ }^{\circ} \mathrm{C}\right)\end{array}$ & $\begin{array}{c}\mathrm{wt} \% \\
\mathrm{CaCl}_{2}\end{array}$ & $\mathrm{wt} \% \mathrm{NaCl}+\mathrm{CaCl}_{2}$ \\
\hline H10 & Barite(MMV) & LV & 8 & -48 & -11 & -23 & 11.4706 & 228 & 3.4696 & 14.9402 \\
\hline H10 & Barite(MMV) & LV & 12 & -45 & -5.2 & -21.2 & 8.3265 & 212 & 0.0221 & 8.3487 \\
\hline H10 & Barite(MMV) & LV & 8 & -52 & -8.5 & -25 & 7.2232 & 216 & 5.2732 & 12.4964 \\
\hline H10 & Barite(MMV) & LV & 10 & -52 & -9.7 & -21.5 & 13.0638 & 218 & 0.6195 & 13.6833 \\
\hline H10 & Barite(MMV) & LV & 7 & -45 & -7.5 & -23 & 8.6993 & 204 & 2.6313 & 11.3307 \\
\hline H10 & Barite(MMV) & LV & 8 & -46 & -6 & -23.7 & 6.629 & 211 & 2.919 & 9.5479 \\
\hline H10 & Barite(MMV) & LV & 8 & -52 & -6 & -22 & 8.3959 & 209 & 1.0624 & 9.4583 \\
\hline H10 & Barite(MMV) & LV & 10 & -52 & -12.8 & -24 & 10.9753 & 223 & 5.5233 & 16.4987 \\
\hline H10 & Barite(MMV) & LV & 10 & -52 & -3.5 & -22 & 5.258 & 209 & 0.6653 & 5.9233 \\
\hline H10 & Barite(MMV) & LV & 8 & -52 & -12 & -23.7 & 10.9883 & 239 & 4.8385 & 15.8268 \\
\hline H10 & Barite(MMV) & LV & 8 & -52 & -6.5 & -21.8 & 9.2139 & 219 & 0.868 & 10.0819 \\
\hline H10 & Barite(MMV) & LV & 10 & -45 & -8 & -21.8 & 10.8396 & 219 & 1.0211 & 11.8607 \\
\hline H11 & Barite(MMV) & LV & 8 & -52 & -13.8 & -23.4 & 12.5698 & 198 & 4.7732 & 17.343 \\
\hline H11 & Barite(MMV) & LV & 8 & -41 & -15.5 & -23 & 14.3622 & 171 & 4.3442 & 18.7064 \\
\hline H11 & Barite(MMV) & LV & 12 & -45 & -12 & -22 & 14.0966 & 195 & 1.7838 & 15.8804 \\
\hline H11 & Barite(MMV) & LV & 8 & -45 & -15.5 & -22 & 16.7064 & 183 & 2.114 & 18.8204 \\
\hline H11 & Barite(MMV) & LV & 8 & -45 & -11 & -22.5 & 12.338 & 199 & 2.6093 & 14.9473 \\
\hline H11 & Barite(MMV) & LV & 8 & -52 & -13.4 & -23.4 & 12.3344 & 173 & 4.6838 & 17.0182 \\
\hline H11 & Barite(MMV) & LV & 10 & -52 & -14 & -22.5 & 14.4996 & 185 & 3.0665 & 17.5661 \\
\hline H11 & Barite(MMV) & LV & 16 & -52 & -13.8 & -23 & 13.3342 & 171 & 4.0333 & 17.3675 \\
\hline H11 & Barite(MMV) & LV & 10 & -45 & -14.5 & -23 & 13.7653 & 195 & 4.1637 & 17.929 \\
\hline H11 & Barite(MMV) & LV & 10 & -45 & -12 & -21.5 & 15.1836 & 185 & 0.72 & 15.9037 \\
\hline H15-1 & Barite(VLB) & LV & 10 & -41 & -10 & -22 & 12.4142 & 143 & 1.5709 & 13.985 \\
\hline H15-1 & Barite(VLB) & LV & 12 & -52 & -12 & -24 & 10.5242 & 170 & 5.2963 & 15.8205 \\
\hline H15-1 & Barite(VLB) & LV & 12 & -45 & -13.5 & -23 & 13.1458 & 153 & 3.9763 & 17.122 \\
\hline H15-1 & Barite(VLB) & LV & 8 & -52 & -10.5 & -22.2 & 12.4807 & 170 & 1.9945 & 14.4752 \\
\hline H15-1 & Barite(VLB) & LV & 8 & -52 & -12.7 & -23.9 & 11.0785 & 214 & 5.34 & 16.4185 \\
\hline H15-1 & Barite(VLB) & LV & 10 & -52 & -16.3 & -24 & 12.7731 & 217 & 6.4281 & 19.2012 \\
\hline H15-1 & Barite(VLB) & LV & 10 & -47 & -17.8 & -22.9 & 15.908 & 189 & 4.5145 & 20.4225 \\
\hline H15-1 & Barite(VLB) & LV & 8 & -45 & -12 & -24.5 & 9.8006 & 190 & 6.011 & 15.8116 \\
\hline H15-1 & Barite(VLB) & LV & 10 & -52 & -12.4 & -22.6 & 13.1873 & 205 & 3.0225 & 16.2098 \\
\hline H15-1 & Barite(VLB) & LV & 16 & -52 & -13.2 & -22.5 & 13.951 & 256 & 2.9505 & 16.9015 \\
\hline H15-1 & Barite(VLB) & LV & 12 & -45 & -11.6 & -21.6 & 14.6137 & 205 & 0.9176 & 15.5313 \\
\hline
\end{tabular}

Bodnar \& Vityk (1994). The $\mathrm{T}_{\mathrm{LM}}$ data yield fluid salinities ranging from 3.62 to $16.70 \mathrm{wt} \% \mathrm{NaCl}$ eq. (Table 1; Fig. 8B), with an average of $13.2 \mathrm{wt} \% \mathrm{NaCl}$ eq. The $\mathrm{Tm}_{\mathrm{hh}}$ value lies between -21 and $-25^{\circ} \mathrm{C}$. As shown in Figure 8B, the salinity for inclusions in the barite samples studied displays two modes at 6 to 8 and 12 to $14 \mathrm{wt} \% \mathrm{NaCl}$ eq. It can therefore be concluded that these samples formed under hydrothermal conditions from hydrothermal fluids (Shepherd et al., 1985). The data on fluid inclusions in barite show that the mineralising fluids were also within the $\mathrm{H}_{2} \mathrm{O}-\mathrm{NaCl}-\mathrm{CaCl}_{2}$ system. Furthermore, the salinity graph vs homogenisation temperature (Fig. 9) (Kesler, 2005) of the fluid inclusions studied shows that the data obtained fall into two fields of basinal and seawater fluids. Salinities of 12 to $14 \mathrm{wt} \% \mathrm{NaCl}$ eq. overlap each other. However, as can be seen in
Figure 10B, there are some significant data with other modes at 6 to $8 \mathrm{wt} \% \mathrm{NaCl}$ eq. falling into the seawater field. Thus, it could be suggested that two different fluids were involved in barite mineralisation, i.e., basinal water and seawater fluids.

\subsection{Geochemistry}

Geochemical analysis of trace and rare earth elements (REE) is a powerful instrument in hydrothermal mineralisation studies, and is used in order to recognise the formation and detect the source of mineralised fluids in different geological environments (Guichard et al., 1979; Jewell \& Stallard, 1991; Bozkaya \& Gökce, 2004; Clark et al., 2004; Jurković et al., 2010; Noguchi et al., 2011). 


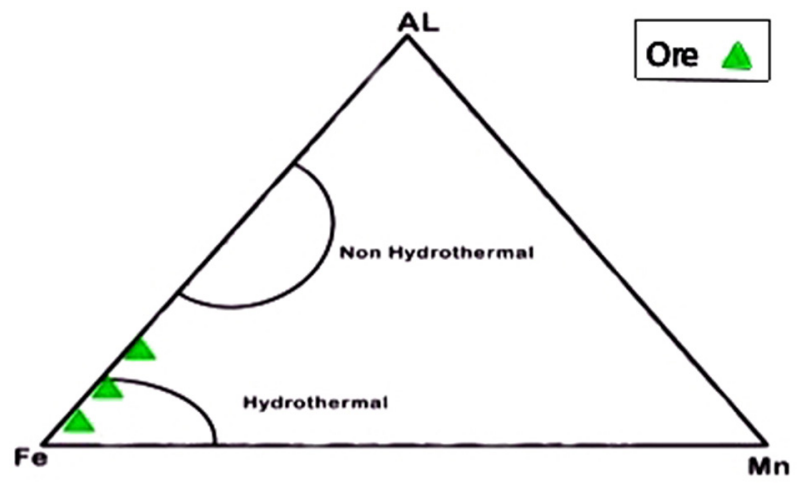

Fig. 10. Al - Fe - Mn ternary diagram of the Ahmadabad hematite samples.

\subsubsection{Major elements}

The contents of major and some trace elements of the Ahmadabad deposit are tabulated in Table 2. $\mathrm{Fe} / \mathrm{Mn}$ ratios are a useful tool for evaluating the type of iron mineralisation. Crerar et al. (1982) indicated that iron deposits formed from early and rapidly deposited hydrothermal solutions showing high $\mathrm{Fe} / \mathrm{Mn}$ ratios $(>10)$ and with a wide range of variations. It is known that the $\mathrm{Fe} / \mathrm{Mn}$ ratio in sedimentary iron deposits is about 1 and shows a narrow range of variation (Bonatti et al., 1972). Rona (1978) and Nicholson (1992) also noted that the Fe/ $\mathrm{Mn}$ ratio in the exhalative iron deposits showed a wide range of variation. The $\mathrm{Fe} / \mathrm{Mn}$ ratio in the hematite mineralised samples of the Ahmadabad deposit varies between 18.33 and 347.21 (Table 2). According to these results, it can be concluded that the manganese (very poor)/ hematite (very rich in iron) mineralisation of the Ahmadabad deposit formed from early and rapidly deposited hydrothermal solutions. In the ternary diagram of Al-Fe-Mn (Adachi et al., 1986) (Fig. 10) the iron hydrothermal deposit can be separated on the basis of ratios AlFe-Mn available from other generative groups. This

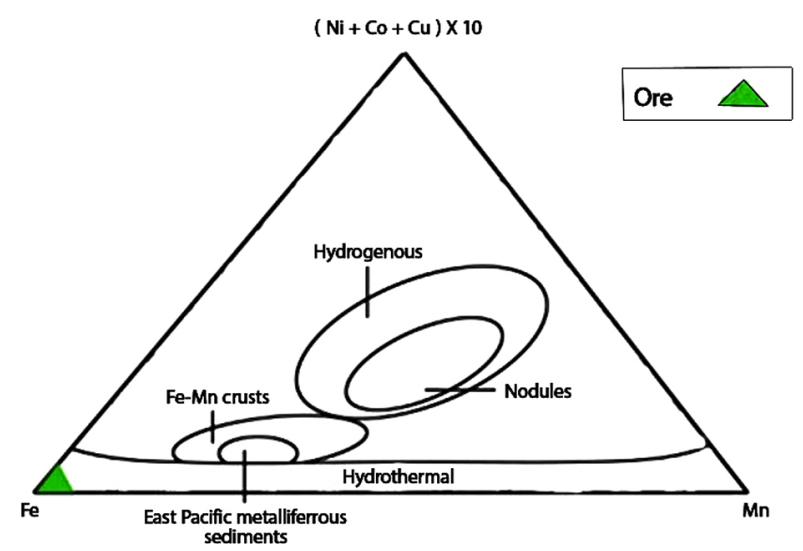

Fig. 11. $\mathrm{Fe}-\mathrm{Mn}-\mathrm{Ni}+\mathrm{Co}+\mathrm{Cu}$ ternary diagram of the Ahmadabad hematite samples.

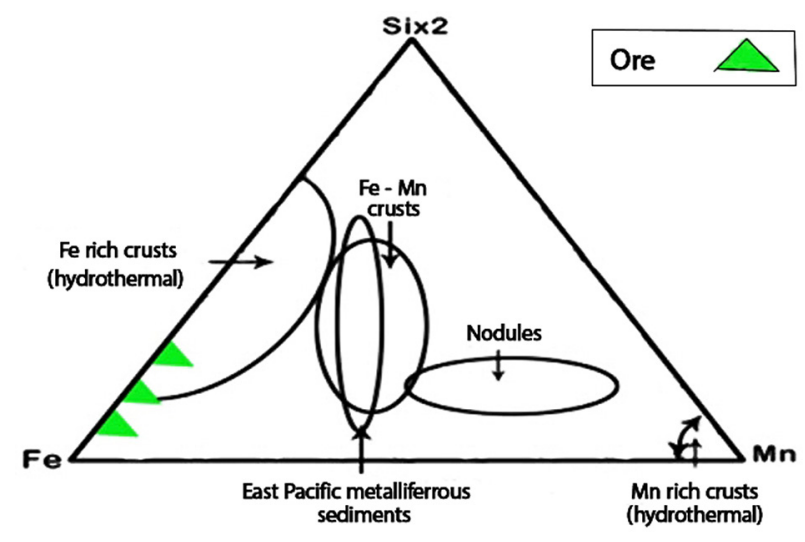

Fig. 12. Fe - Mn - Si ternary diagram (Corliss \& Dymond, 1975) of the Ahmadabad hematite samples.

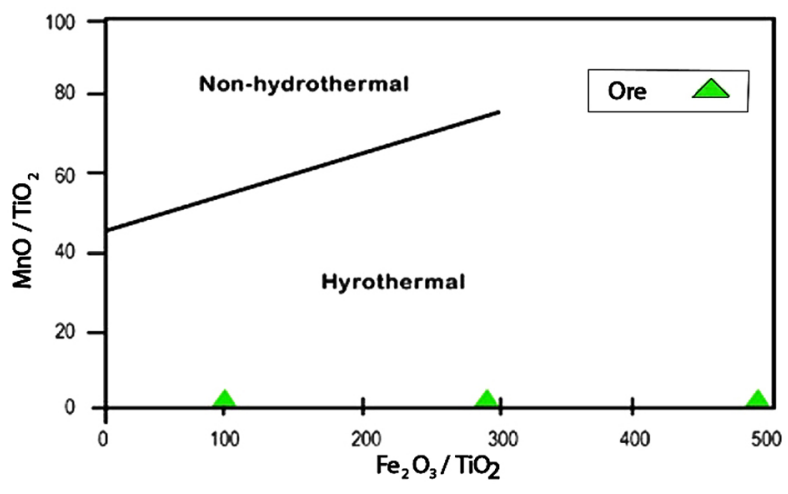

Fig. 13. $\mathrm{MnO} / \mathrm{TiO}_{2}-\mathrm{Fe}_{2} \mathrm{O}_{3} / \mathrm{TiO}_{2}$ diagram of the Ahmadabad hematite samples.

diagram can mostly be used for iron-rich deposits. As shown, the hematite samples of the Ahmadabad ore fall into the field of hydrothermal iron deposits. Figure 11 shows the ternary diagram of Fe-Mn-(Ni + Co + Cu) X10 (Bonatti et al., 1972; Crerar et al., 1982) in which the Ahmadabad hematite samples are found in the hydrothermal iron deposit field. In the Fe-Mn-SiX2 ternary diagram (from Adachi et al., 1986), the Ahmadabad hematite samples fall into the Fe-rich hydrothermal field, as is also shown in Figure 12. Furthermore, from the $\mathrm{MnO} / \mathrm{TiO}_{2}-$ $\mathrm{Fe}_{2} \mathrm{O}_{3} / \mathrm{TiO}_{2}$ diagram (Adachi et al., 1986) it is clear that the hematite samples lie in the field of hydrothermal iron deposits (Fig. 13).

\subsubsection{Trace elements}

Values of 39 trace elements have been identified and compared, in four groups, of samples from hematite and barite veins, host rocks and quartz latite. Only six elements were detected (in addition to REEs) in all hematite and barite samples, whereas the other elements were lacking in at least one of the barite samples (Table 2). As can be seen from Table 2, the concentrations of $\mathrm{Pb}, \mathrm{Zn}, \mathrm{Hg}, \mathrm{Cu}$ and $\mathrm{Sb}$ in the host- 
rock samples are one to three orders of magnitude higher than in the barite samples. This implies that $\mathrm{Ba}$ and $\mathrm{Sr}$ enrichment in the Ahmadabad barite de- posit was accompanied by depletion of $\mathrm{Pb}, \mathrm{Zn}, \mathrm{Hg}$, $\mathrm{Cu}$ and $\mathrm{Sb}$. Sr shows enrichment in the Ahmadabad barite sample which could have been caused by $\mathrm{Sr}$ -

Table 2. Major, trace and rare earth element analyses in samples studied by ICP-ES and ICP-MS and XRF.

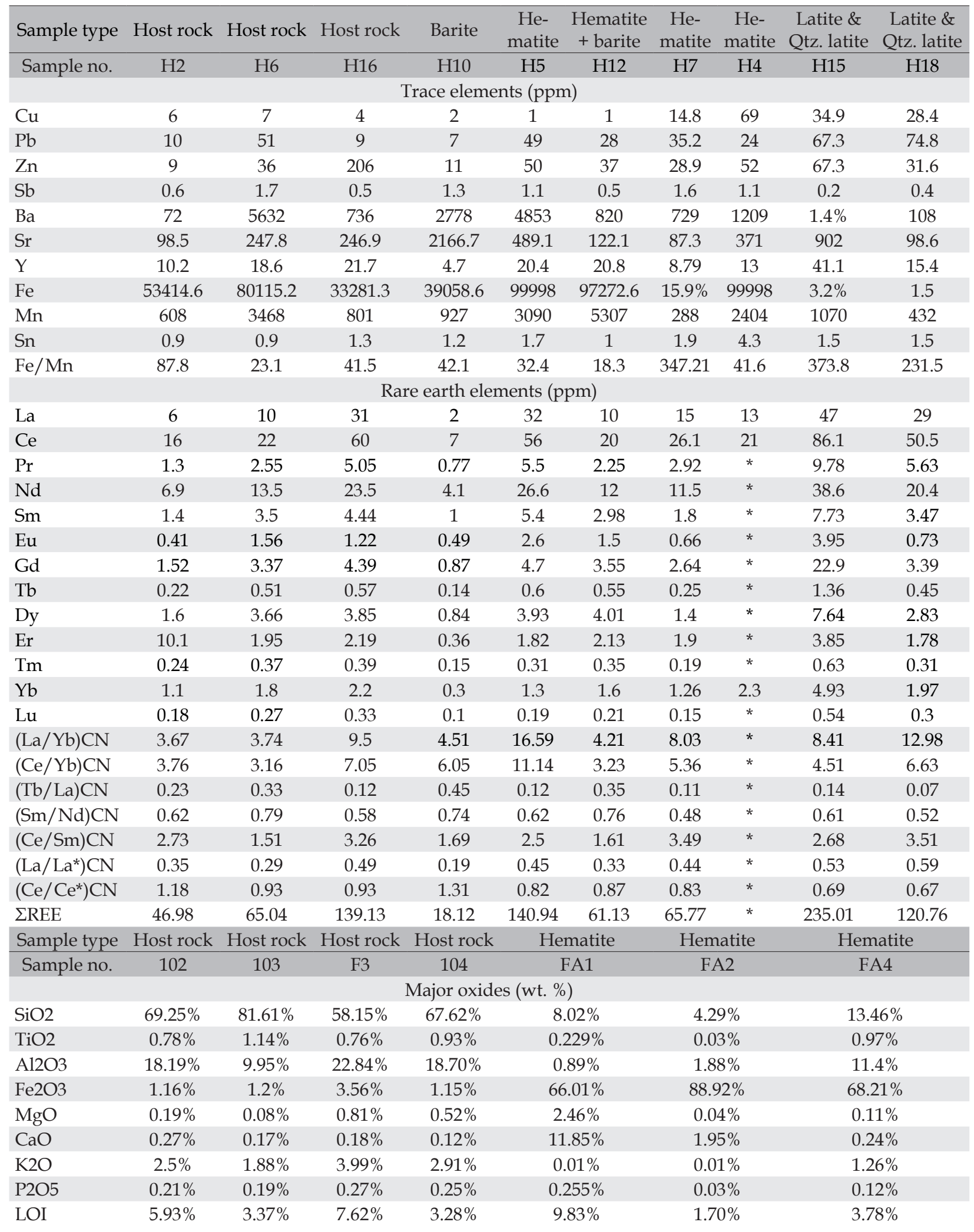


Ba substitution in the crystal structure of barite and it is related to the formation of barite-celestite solid solution series. The relatively high $\mathrm{Sr}$ concentration in the barite sample indicates an origin of the Ahmadabad barite deposit from a low-temperature hydrothermal solution (e.g., Kato \& Nakamura, 2003; Jurković et al., 2010).

\subsubsection{Rare earth elements}

The rare earth element (REE) concentrations of samples studied are presented in Table 2. The REE concentrations are normalised using the average chondrite abundances of McDonough \& Sun (1995). In order to identify REE behaviour in the host rock, quartz latite, hematite and barite samples, the ratios of $\mathrm{La}_{\mathrm{N}} / \mathrm{Yb}_{\mathrm{N}^{\prime}} \mathrm{Ce}_{\mathrm{N}} / \mathrm{Yb}_{\mathrm{N}}, \mathrm{Tb}_{\mathrm{N}} / \mathrm{La}_{\mathrm{N}}, \mathrm{Sm}_{\mathrm{N}} / \mathrm{Nd}_{\mathrm{N}}$ and $\mathrm{Ce}_{\mathrm{N}} /$ $\mathrm{Sm}_{\mathrm{N}}$ were used (Table 2). Based on these results, it can be concluded that the $\mathrm{La}_{\mathrm{N}} / \mathrm{Yb}_{\mathrm{N}^{\prime}}, \mathrm{Tb}_{\mathrm{N}} / \mathrm{La}_{\mathrm{N}}, \mathrm{Sm}_{\mathrm{N}} /$ $\mathrm{Nd}_{\mathrm{N}}$ and $\mathrm{Ce}_{\mathrm{N}} / \mathrm{Sm}_{\mathrm{N}}$ ratios of hematite samples are very similar to ratios of quartz latite subvolcanic body sample. Furthermore, the values of $\mathrm{La}_{\mathrm{N}} / \mathrm{Yb}_{\mathrm{N}^{\prime}}$ $\mathrm{Tb}_{\mathrm{N}} / \mathrm{La}_{\mathrm{N}}, \mathrm{Sm}_{\mathrm{N}} / \mathrm{Nd}_{\mathrm{N}}$ and $\mathrm{Ce}_{\mathrm{N}} / \mathrm{Sm}_{\mathrm{N}}$ of the barite sample are similar to ratios of the host rocks. Thus, it could be inferred that the origin of iron mineralisation is related to quartz latite and the origin of barite mineralisation is related to volcanic host rocks.

Ce anomaly. According to Ruhlin \& Owen (1986) and Bhattacharya et al. (2007), the Ce anomaly was measured for hematite, barite, host rock and quartz latite samples, using the following formula: $\mathrm{Ce} /$ $\mathrm{Ce}^{*}=\log \left[\mathrm{Ce}_{\mathrm{N}} /\left(2 / 3 \mathrm{La}_{\mathrm{N}}+1 / 3 \mathrm{Nd}_{\mathrm{N}}\right)\right]$. The results obtained (Table 2) indicate a close similarity between the values of hematite and quartz latite samples. This allows the conclusion that the origin of iron mineralisation could be related to the quartz latite lithological unit.
La anomaly. According to Bolhar et al. (2004), the La anomaly was measured for hematite, barite, host rock and quartz latite, using the following formula: $\mathrm{La} / \mathrm{La}^{*}=\mathrm{La}\left(3 \mathrm{Pr}_{\mathrm{N}}-2 \mathrm{Nd}_{\mathrm{N}}\right)$. The calculated values (Table 2) also show a close similarity between the values of hematite and quartz latite. Furthermore, the La anomaly of the host rock samples indicates depletion in comparison with the hematite samples. This can have been caused by La transportation by mobile parts during the hydrothermal fluid flow from host rocks (Hajalilou et al., 2014). As a result, a notable La deficiency in host rocks can be observed. The La might also have been transported from host rocks as a result of the formation of some complexes with F (Palinkas et al., 1994).

\subsection{Chondrite normalised patterns}

The REE concentrations of the Ahmadabad hematite-barite deposit (Table 2), normalised using the chondrite abundances of Boynton (1984), show the total REE ( $\mathrm{REE}$ ), varying from 46.98 to 235.01 ppm, with a mean of $99.21 \mathrm{ppm}$. The patterns of chondrite normalised data of samples studied show an LREE enrichment, as opposed to HREE, with a negative uniform slope with Eu positive anomalies and much more Gd (Fig. 14). The chondrite normalised REE patterns of hematite, barite, host rocks and quartz latite samples are shown as separate diagrams. Based on changes in REE patterns between barite and hematite, a dual origin for hydrothermal fluids can be deduced for the ore-forming fluid in the Ahmadabad deposit (Zamanian \& Radmard, 2016) (Fig. 15).
Fig. 14. Chondrite normalised REE patterns of the Ahmadabad hematite/ barite deposit. Chondrite data for normalisation are from Boynton (1984).

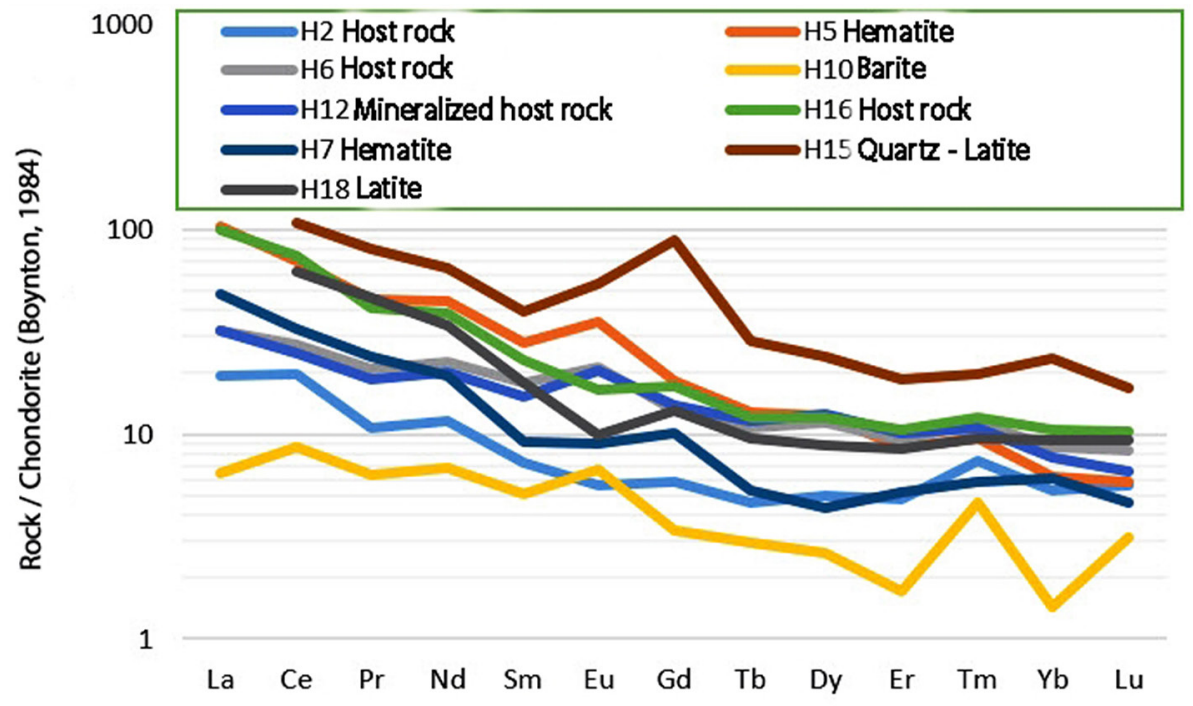



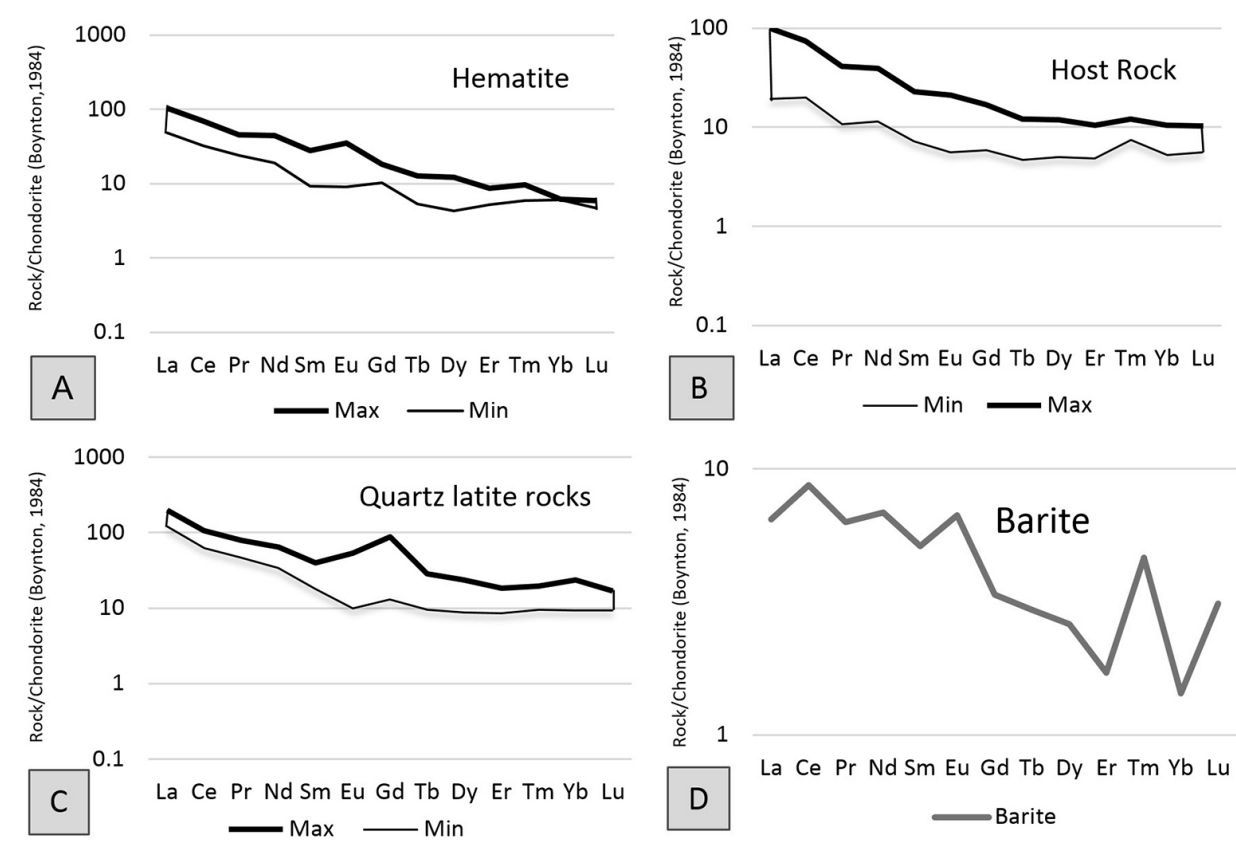

Fig. 15. Chondrite normalised REE patterns. A - Hematite mineralised vein; $\mathbf{B}$ - Host rocks; C - Qtz. Latite \& Latite subvolcanic body; D - Barite mineralised vein.
4.5.1. Difference between barite and hematite in chondrite normalised REE patterns

As can be seen in Figure 16, there is a significant difference between the values of chondrite normalised patterns of hematite and barite samples. In the chondrite normalised pattern of hematite samples, LREE start from values higher than $100 \mathrm{ppm}$ and have a descending trend towards HREE reaching lower than $10 \mathrm{ppm}$. In the chondrite normalised pattern of barite sample, LREE start from values of about $10 \mathrm{ppm}$ and have a descending trend towards HREE reaching close to 1ppm. In general, compared to barite sample, hematite samples show obvious enrichment in $\Sigma$ REE and significant enrichment of LREE than HREE. It indicates that two different hydrothermal fluids played a role in hematite and barite mineralisations.

\subsubsection{Similarity between hematite and quartz latite}

Chondrite normalised REE patterns of hematite samples (Fig. 15A) compared with those of quartz latite samples (Fig. 15C) show a strong similarity between the two samples. However, there is an enrichment of MREE in the patterns which can be due to the presence of the amphibole minerals in the quartz latite. These similarities suggest that the hematite-forming hydrothermal fluids might have originated from the quartz latite lithological unit.

\subsection{Comparison of the Ahmadabad barite deposit with other barite deposits}

As seen in Figure 15D, the chondrite normalised REE pattern of the Ahmadabad barite sample is in a range between $10 \mathrm{ppm}$ to close to $1 \mathrm{ppm}$ with a tendency towards more depletion with a negative total slope. The review of changes in REE values of barite sample shows positive anomalies of $\mathrm{Ce}, \mathrm{Sm}, \mathrm{Tm}$ and $\mathrm{Lu}$, and reveals negative anomalies in $\mathrm{La}, \mathrm{Pr}, \mathrm{Nd}$, $\mathrm{Eu}, \mathrm{Er}$ and $\mathrm{Yb}$. A comparison between the chondrite normalised REE pattern of the Ahmadabad barite with barite of an oceanic origin (Guichard et al.,

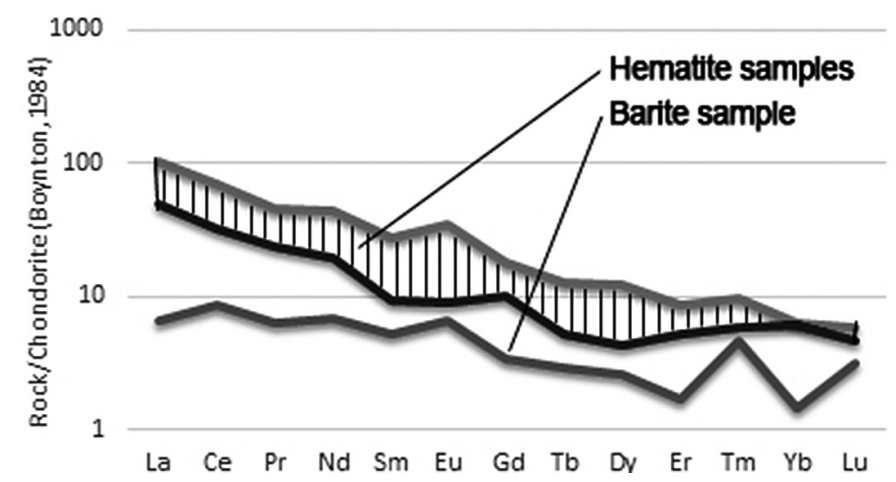

Fig. 16. Chondrite normalised REE patterns of barite and hematite samples. 


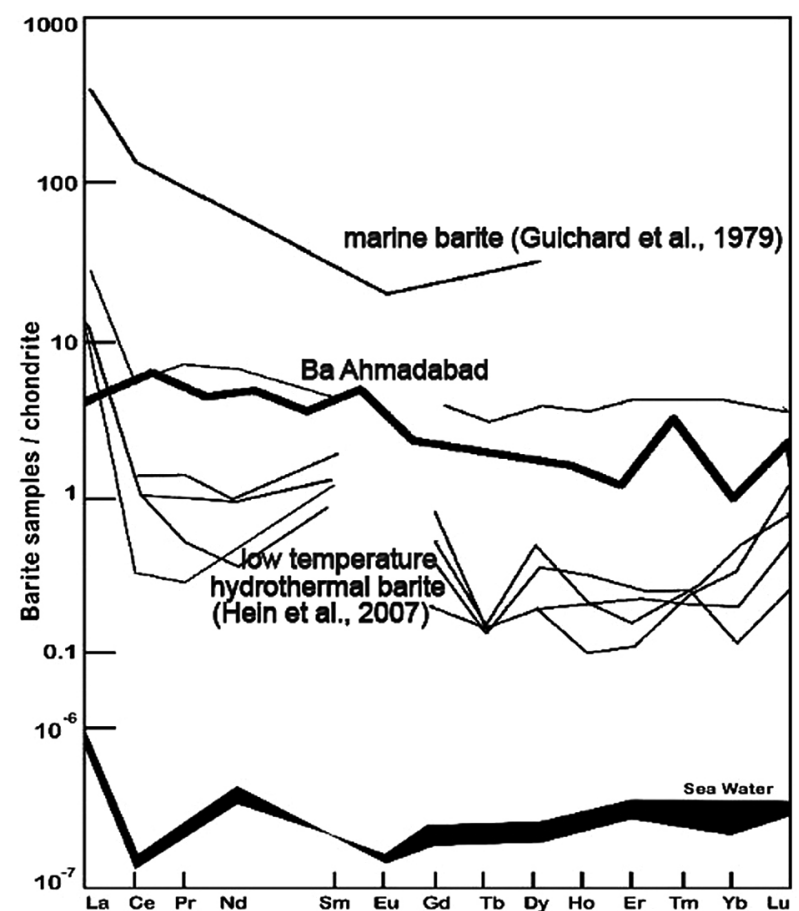

Fig. 17. Comparison of chondrite normalised REE patterns of the Ahmadabad barite deposit and other barite deposits.

1979; Murray et al., 1990; Alexander et al., 2008) and low temperature hydrothermal barite (Guichard et al., 1979; Hein et al., 2007) indicates a few close similarities with low-temperature hydrothermal barite deposits (Fig. 17).

\section{Conclusions}

The Ahmadabad hematite/barite deposit occurs as a vein-type deposit within Eocene volcanic host rocks. The principal minerals which constitute the mineralised vein are hematite, barite, pyrite, limonite and other Fe-oxyhydroxide minerals. Based on fluid inclusion studies conducted on two-phase liquid-vapour inclusions of barite samples which vary in size from 7 to $16 \mu \mathrm{m}, \mathrm{T}_{\mathrm{H}}$ values obtained lie between 142 to $256^{\circ} \mathrm{C}$ with a peak temperature of 200 to $220^{\circ} \mathrm{C}$, the $\mathrm{Tm}_{\mathrm{i}}$ values range from -17.8 to $-2.7^{\circ} \mathrm{C}$ and the salinity of the fluids range between 3.62 to $16.70 \mathrm{NaCl} w t \%$. The salinity vs. homogeneous temperature histogram of the fluid inclusions suggest that two different fluids would have been involved in the mineralisation of barite, including basinal water and seawater fluids. The geochemical characteristics of trace elements, such as high concentrations of $\mathrm{Ba}$ and $\mathrm{Sr}$ accompanied by depletion of $\mathrm{Cu}, \mathrm{Zn}, \mathrm{Pb}, \mathrm{Sb}$ in the barite sample, indicate that the Ahmadabad hematite/barite mineralisa- tion probably originated from low-temperature ore-forming hydrothermal fluids. A comparison between the chondrite normalised REE patterns of the Ahmadabad barite deposit and other barite deposits indicates that there are similarities between the Ahmadabad barite deposit and low-temperature hydrothermal barite deposits. Furthermore, based on a study of major and minor element contents of the Ahmadabad hematite samples and comparison with different types of iron deposits, it is concluded that the Ahmadabad hematite mineralisation can be categorised as a hydrothermal iron ore. Moreover, by investigating the values of chondrite normalised REEs in samples from host rocks, quartz latite, hematite and barite, and by calculating the $\mathrm{La}_{\mathrm{N}} / \mathrm{Yb}_{\mathrm{N}^{\prime}}$ $\mathrm{Tb}_{\mathrm{N}} / \mathrm{La}_{\mathrm{N}}, \mathrm{Sm}_{\mathrm{N}} / \mathrm{Nd}_{\mathrm{N}}, \mathrm{Ce}_{\mathrm{N}} / \mathrm{Sm}_{\mathrm{N}}, \mathrm{Ce} / \mathrm{Ce}^{*}$ and $\mathrm{La} / \mathrm{La}^{*}$ ratios, it follows that there are significant similarities between the values of hematite samples and quartz latite samples. Furthermore, the values obtained from these ratios indicate a strong similarity between the barite sample and host rock samples. These findings suggest that hematite mineralisation could have originated from quartz latite surrounding rocks, and that barite mineralisation could have originated from volcanic host rocks.

\section{Acknowledgements}

We are grateful to anonymous reviewers for commenting on an earlier version of the typescript and supplying valuable suggestions.

\section{References}

Adachi, M., Yamamoto, K. \& Sugisaki, R., 1986. Hydrothermal charts and associated silicious rocks from northern Pacific: their geological significance as indication of ocean ridge activity. Sedimentary Geology 47, 148-125.

Alavi, M., 2005. JAM Geology Map 1:100,000, Geological Society of Iran. Tehran Iran.

Alexander, B.W., Bau, M., Andersson, P. \& Dulski, P., 2008. Continentally derived solutes in shallow Archean seawater: rare earth element and $\mathrm{Nd}$ isotope evidence in iron formation from the 2.9 Ga Pongola Supergroup, South Africa. Geochimica et Cosmochimica Acta 72, 378-394.

Bhattacharya, H.N., Chakraborty, I. \& Ghosh, K., 2007. Geochemistry of some banded iron formations of the Archean supracrustal, Jharkhand-Orissa region, India. Journal of Earth System Science 116, 245-259.

Bodnar, R.J. \& Vityk, M.O., 1994. Interpretation of micro thermometric data for $\mathrm{H} 2 \mathrm{O}-\mathrm{NaCl}$ fluid inclusions. [In:] B. De Vivo \& M.L. Frezzotti (Eds): Fluid inclusions 
in minerals - methods and applications. Virginia Tech., Blacksburg, 117-130.

Bolhar, R., Kamber, B.S., Moorbath Fedo, C.M. \& Whitehouse, M.J., 2004. Characterization of early Archean chemical sediments by trace elements. Earth and Planetary Science Letters 222, 43-60.

Bonatti, E., Kraemer, T. \& Rydell, H., 1972. Classification and genesis of submarine iron-manganese deposits. [In:] Horn, D. (Ed.): Ferromanganese deposits on the ocean floor. Natl. Sci. Found, Washington, 149-166.

Boynton, W.V., 1984. Geochemistry of the REE meteorite studies. [In:] Henderson, P. (Ed.): REE Geochemistry. Elsevier, 63-114.

Bozkaya, G. \& Gökce, A., 2004. Trace- and rare-earth elements geochemistry of the Karalar (Gaipasa-Antalya) barite-galena deposits, Southern Turkey. Turkish Journal of Earth Sciences 13, 63-75.

Clark, H.B, Poole, F.G. \& Wang, Z., 2004. Comparison of some sediment hosted, stratiform barite deposits in China, the United States, and India. Ore Geology Reviews 24, 85-101.

Corliss, J.B. \& Dymond, J., 1975. Nazca Plate metalliferous sediments: I. Elemental Distribution patterns in surface samples. EOS Transactions, American Geophysical Union 56, 445.

Crerar, D.H., Namson, J., Chyi, M.S., Williams, L. \& Feigenson, M.D., 1982. Manganiferous cherts of the Franciscan Assemblage: I. General geology, ancient and modern analoques and implications for hydrotermal convenction at oceanic spreading centers. Economic Geology 77, 519-540.

Evans, A.M., 2009. Ore Geology and Industrial Minerals. An Introduction. Wiley, 389.

Ghorbani, M., 2013. The Economic Geology of Iran. Springer, $570 \mathrm{pp}$.

Guichard, F., Church, T.M., Treuil, M. \& Jaffrezic, H., 1979. Rare earth elements in brites: distribution and effects on aqueous partitioning. Geochemica et Cosmochemica Acta 49, 983-997.

Hajalilou, B., Vusuq, B. \& Moayed, M., 2014. REE geochemistry of Precambrian shale-hosted barite-galena mineralization, a case study from NW Iran. Journal of Crystallography and Mineralogy 22, 39-48.

Hein, J.R., Zierenberg, R.A., Maynard, J.B. \& Hannington, M.D., 2007. Barite-forming environments along a rifted continental margin, southern California borderland. Deep Sea Research part 2. Tropical Studies in Oceanography 54, 1327-1349.

Jewell, P.W \& Stallard, R.F., 1991. Geochemistry and paleoceanographic setting of central Nevada bedded barites. Journal of Geology 99, 151-170.

Jurković, I., Garašić, V. \& Hrvatović, H., 2010. Geochemical characteristics of barite occurrences in the Palaeozoic complex of south-eastern Bosnia and their relationship to the barite deposits of the mid-Bosnian Schist Mountain. Geologia Croatica 63, 241-258.
Kato, Y. \& Nakamura, K., 2003. Origin and global tectonic significance of early Archean cherts from the Marble Bar greenstone belt, Pilbara Craton, Western Australia. Precambrian Research 125, 191-243.

Kato, Y., 1999. Rare earth elements as an indicator to origins of skarn deposits: Examples of the Kamioka $\mathrm{Zn}-\mathrm{Pb}$ and Yoshiwara-Sannotake Cu (-Fe) deposits in Japan. Resource Geology 49, 183-198.

Kesler, S.E., 2005. Ore-forming fluids. Elements 1, 13-18.

McDonough, W.F., Sun, S.S., 1995. The composition of the earth. Chemical Geology 120, 223-253.

Murray, RW., Buchholtz ten Brink, M.R., Jones, D.L., Gerlach, D.C. \& Russ, G.P., 1990. Rare earth elements as indicators of different marine depositional environments in chart and shale. Geology 18, 268-271.

Nicholson, K., 1992. Contrasting minerological-geochemical signatures of manganese oxides: Guides to metallogenesis. Economic Geology 87, 1253-1264.

Noguchi, T., Shinjo, R., Ito, M., Takada, J. \& Oomori, T., 2011. Barite geochemistry from hydrothermal chimneys of the Okinawa Trough: insight into chimney formation and fluid/sediment interaction. Journal of Mineralogical and Petrological Sciences 106, 26-35.

Palinkas, L.A. \& Jurkovic, I., 1994. Lanthanide geochemistry and fluid inclusion peculiarities of the fluorite form the barite deposits south of Kresevo (Bosnia and Herzegovina). Geologia Croatica 47, 103-115.

Roedder, E., 1984. Fluid inclusions. Reviews in Mineralogy, vol. 12. Mineralogical Society of America, 644 pp.

Rona, P.A., 1978. Criteria for recognition of hydrothermal mineral deposits in oceanic crust. Economic Geology 73, 135-160.

Ruhlin, D.E. \& Owen, M., 1986. The REE geochemistry of hydrothermal sediments from the East Pacific rise: Examination of a seawater scavenging mechanism. Geochemica et Cosmochemica Acta 50, 393-400.

Shepherd, T.J., Ranbin, A.H. \& Alderton, D.H.M., 1985. A practical guide to fluid inclusion studies. Blackie, Glasgow, 239 pp.

Ulrich, M.R. \& Bodnar, R.J., 1988. Systematics of stretching of fluid inclusions II: barite at 1 atm confning pressure. Economic Geology 83, 1037-1046.

Zamanian, H. \& Radmard, K., 2016. Geochemistry of rare earth elements in the Baba Ali magnetite skarn deposit, western Iran - a key to determine conditions of mineralization. Geologos 22, 33-47.

Zarasvandi, A., Zaheri, N., Pourkaseb, H., Chrachi, A. \& Bagheri, H., 2014. Geochemistry and fluid-inclusion micro thermometry of the Farsesh barite deposit, Iran. Geologos 20,201-214.

Manuscript received: 24 March 2017 Revision accepted: 5 January 2018 